\title{
Patient safety in organizational culture as perceived by leaderships of hospital institutions with different types of administration*
}

\author{
Segurança do paciente na cultura organizacional: percepção das lideranças \\ de instituições hospitalares de diferentes naturezas administrativas \\ Seguridad del paciente en la cultura organizativa: percepción de los liderazgos \\ de instituciones hospitalarias de distintas naturalezas administrativas
}

Natasha Dejigov Monteiro da Silva ${ }^{1}$, Antonio Pires Barbosa ${ }^{1}$, Kátia Grillo Padilha², Ana Maria Malik ${ }^{3}$

How to cite this article:

Silva NDM, Barbosa AP, Padilha KG, Malik AM. Patient safety in organizational culture as perceived by leaderships of hospital institutions with different types of administration. Rev Esc Enferm USP. 2016;50(3):487-494. DOI: http://dx.doi.org/10.1590/S0080-623420160000400016

* Extracted from the dissertation "A segurança do paciente na cultura organizacional: tornando o ambiente hospitalar mais seguro", Universidade Nove de Julho, 2014.

${ }^{1}$ Universidade Nove de Julho, São Paulo, SP, Brazil.

${ }^{2}$ Universidade de São Paulo, Escola de Enfermagem, São Paulo, SP, Brazil.

${ }^{3}$ Fundação Getúlio Vargas, Escola de Administração de Empresas, São Paulo, SP, Brazil.

\begin{abstract}
Objective: To identify the perceptions of leaderships toward patient safety culture dimensions in the routine of hospitals with different administrative profiles: government, social and private organizations, and make correlations among participating institutions regarding dimensions of patient safety culture used. Method: A quantitative crosssectional study that used the Self Assessment Questionnaire 30 translated into Portuguese. The data were processed by analysis of variance (ANOVA) in addition to descriptive statistics, with statistical significance set at $\mathrm{p}$-value $\leq 0.05$. Results: According to the participants' perceptions, the significant dimensions of patient safety culture were 'patient safety climate' and 'organizational learning', with $81 \%$ explanatory power. Mean scores showed that among private organizations, higher values were attributed to statements; however, the correlation between dimensions was stronger among government hospitals. Conclusion: Different hospital organizations present distinct values for each dimension of patient safety culture and their investigation enables professionals to identify which dimensions need to be introduced or improved to increase patient safety.
\end{abstract}

\section{DESCRIPTORS}

Patient Safety; Organizational Culture; Health Services Administration; Quality of Health Care.
Corresponding author:

Natasha Dejigov Monteiro da Silva

Rua Dr. Ovídio Pires de Campos, 225 - Prédio da Administração - $5^{\circ}$ andar - Cerqueira César CEP 05403-010 - São Paulo, SP, Brazil

nadejigov@yahoo.com.br
Received: 05/19/2015

Approved: 05/05/2016 


\section{INTRODUCTION}

Despite the ancient medical principle of "do no harm", unsafe health care seems to cause significant morbidity and mortality worldwide ${ }^{(1-2)}$. In the last three decades, there have been numerous studies on the risks to which patients are exposed while receiving health care, and patient safety has been indicated as a public health challenge ${ }^{(3)}$. When left untreated or unmitigated, these risks can materialize in the form of health incidents. According to the World Health Organization (WHO), health incidents are defined as circumstances that have the potential to cause patients harm. They can be classified as reportable circumstances - situations in which there was significant potential for harm, but that did not result in an incident; a near miss - a situation that could have reached the patient, causing harm or no harm, but that was intercepted beforehand, also called a potential adverse event; a no harm incident; and a harmful incident, also known as an adverse event ${ }^{(4-5)}$.

In one Brazilian study on harm caused to patients, 1,218 adverse events (AEs) were identified among 468 patients admitted to an emergency service due to cerebrovascular accidents $^{(6)}$. Another prominent Brazilian study demonstrated that the incidence of AEs in Brazilian hospitals was $7.6 \%$ (84 of 1,103 patients) and the proportion of avoidable events was $66.7 \%$ (56 of 84 patients) ${ }^{(7)}$. Reinforcing this scenario, another study showed that of 399 ICU admissions, 74.2\% (296) suffered at least one $\mathrm{AE}^{(8)}$.

Patient safety is considered a dimension of quality of care and is defined as the reduction of risk of unnecessary healthcare-related harm to an acceptable minimum ${ }^{(9)}$. To improve the quality of and increase patient safety, interdisciplinary teams must be integrated with the help of high management, i.e., with the support of the people who make decisions about an organization's fate ${ }^{(10)}$ and whose efforts to correct unsafe processes, in alignment with the organization's vision, mission and values, enable change in patient safety culture and organizational culture. These changes, in turn, are reflected in shared behaviors, beliefs, attitudes and values regarding goals, functions and procedures ${ }^{(11-13)}$.

Safety culture is defined by Resolution n. 36/2013 by Agência Nacional de Vigilância Sanitária as "a set of values, attitudes, competencies and behaviors that determine commitment to health management and safety, replacing blame and punishment with the opportunity to learn with mistakes and improve health care" ${ }^{\prime(13)}$. Among the characteristics of a solid safety culture, some actions stand out, such as: recognizing the unavoidable nature of mistakes; discussing and learning from mistakes; proactively identifying threats; and incorporating a nonpunitive system for reporting and analyzing $\mathrm{AEs}^{(14-15)}$. However, changes or results are not immediate; patience and persistence are required to reach a strengthened safety culture ${ }^{(16)}$.

In Brazil, hospitals represent 2.34\% $(6,319)$ of the national healthcare facilities, of which 5,220 are classified as general and 1,099 as specialized ${ }^{(17)}$. The city of São Paulo contains 3.13\% (198) of the total number of hospitals in the country, of which $146(2.80 \%)$ are general and $52(4.73 \%)$ are specialized hospitals ${ }^{(17)}$. Of this total, $33(16.67 \%)$ are managed directly by the government, 91 (45.96\%) by private enterprises and $50(25.25 \%)$ by charitable organizations ${ }^{(17)}$.

Considering that different types of institution administration can imply different patient safety cultures and the fact that hospitals are the most susceptible places for the occurrence of AEs, given the amount of procedures carried out, increased time of patient exposure, and the number of professionals involved in health care provision, the aim of this study was to identify the perceptions of hospital leadership towards the dimensions of patient safety culture in the routine of health organizations with different management profiles: private hospitals, public hospitals managed via management contracts (social organizations) and public hospitals managed directly by the government or autonomous organizations (autarchies) in the municipality of São Paulo, Brazil. Autarchies are defined as legal entities of public law, created by law, to provide services characteristic of public administration in a decentralized manner, and whose staff and budget are governed by a legal framework provided for by the mother-entity law ${ }^{(18)}$. Furthermore, the aim was also to correlate different participating institutions according to dimensions of the established patient safety culture.

\section{METHOD}

This was a cross-sectional quantitative study that assessed safety culture in hospitals with different administration models.

To conduct this investigation, we applied the Self Assessment Questionnaire 30 (SAQ 30) ${ }^{(19)}$, freely available on the Emergency Care Research Institute (ECRI) website. The instrument was developed for health institutions to assess the perception of professionals towards organizational patient safety programs, practices and culture. Participants are asked to express their opinion about 91 statements via a 5-point Likert scale. The values on the scale range from completely disagree (1) to completely agree (5). In addition to the items directly related to the theme of the study, seven questions addressed the profile of participants.

The study was submitted to and approved by a research ethics committee under no. 741.962 , requested via the Plataforma Brasil tool.

The convenience sample consisted of 20 hospitals representative of the different administrative categories object of this study. Of these, 11 expressed interest in participating: two private hospitals, three administered via management contracts (social organizations), three hospitals run directly by the government, and three by autarchies. After receiving the approval of the research ethics committee of each institution, the research project was presented to the CEO of each organization, with emphasis on the importance and the aims of the study. Following this first contact, strategic representative leaders from each of the following areas were invited to answer the questionnaire: Clinical Staff, 
Nursing, Physical Therapy, Clinical Pharmacy, Nutrition, Clinical Engineering, Radiology, Reception, Supplies, Storeroom, Risk Management/Quality Management and Cleaning and Laundry. These leaderships occupied management or coordinating positions, totaling 13 professionals per institution.

Participation in the study was voluntary and the following inclusion criteria were applied: minimum 1 year of professional experience; minimum 6 months of experience at the institution; minimum 6 months of experience in current position; and at least 10 hours/week workload at the institution. The professionals were approached in their work environment during their free time, between September and October 2014. Participants received the questionnaires and returned them at a later and previously scheduled time. Participants signed two copies of the informed consent form, one of which they retained and the other returned to the researcher. Also, the researcher instructed the participants on how to respond to the statements in the questionnaire using the established scale. Only one of the organizations used an electronic version of the scale via Google Docs and the consent form was scanned and sent to the researcher via e-mail.

The data were inserted in a Microsoft Office 2010 Excel spreadsheet and were later processed and analyzed. Descriptive statistics were used for calculating the mean, median, standard deviation and percentages. Furthermore, inferential statistics were also used, with analysis of variance (ANOVA) and analysis of correlation via Pearson Coefficient $\left(\mathrm{R}\right.$ and $\mathrm{R}^{2}$ ). The chosen compound linear regression model chosen was the method of least squares, being that inferential linear approximation resulted in a standard trajectory. The matrix method of inference was used via an unmeasured estimate of $\beta$. To perform statistic calculations STATA $^{\mathrm{TM}}$ software version 12.1 was employed.

For data analysis, the questionnaire items were grouped according to dimensions of patient safety culture to assess the hospital organization. The definitions of each of the measurable dimensions are described below and help to understand the assessment of patient safety culture: Expectations and Actions promoting Patient Safety (A): how the staff perceives improvements related to safety and the recognition of the importance of staff participation in the process; Hospital Management Support and Investment in Patient Safety (B): perception of whether hospital administration and management establish a work climate that encourages and prioritizes patient safety; Patient Safety Climate (C): the provision of infrastructure, resources (material, technological, human and financial) and procedures relevant to the development of a safety culture; Communication Openness and Nonpunitive Response to Error (D): perception regarding the freedom to talk openly about risks and errors that can reach patients; Organizational Learning (E): perception of the existence of learning from mistakes and the identification of the effectiveness of changes based on such mistakes;
Teamwork (F): perception of the relationship and treatment among staff within units and whether hospital units cooperate and promote quality of patient care; Feedback and communication about error $(\mathrm{G})$ : perception of conduct (implementing changes, discussing strategies to avoid recurring errors, etc.) after an event is reported.

The established dimensions were classified as categorical and numeric quantitative and qualitative variables, including social and professional characteristics of the participants (I1 to I7), Type of Administration (TA) and Accreditation (AC) of participating organizations, and variables related to perceptions of patient safety. To work with the data, the qualitative variables were converted into numeric ones using a Likert scale. Thus, the entire inferential analysis was quantitative. The dimension 'Expectations and Actions Promoting Patient Safety' (EAPPS) was considered a dependent variable and the other dimensions, independent variables. For analysis, $\mathrm{p}$-values $\leq 0.05$ were considered statistically significant for a confidence interval of $95 \%$.

\section{RESULTS}

Of the 11 hospital institutions that authorized this study, eight sent an official acceptance letter from their respective research committees. In these eight institutions, the questionnaire was applied to the professional group object of study and of the 104 questionnaires given to participants, 103 were returned. The mean number of questionnaires filled out per hospital was 13 .

Among the respondents, 94.2\% reported never having participated in a study similar to this, whereas $5.8 \%$ reported having done so. As regards professional training, the sample consisted of nurses (33\%), physicians (19.4\%), administrators (9.7\%), pharmacists (8.7\%), physical therapists $(7.8 \%)$, dieticians $(5.8 \%)$, engineers $(5.8 \%)$, economists $(1.0 \%)$, speech therapists $(1.0 \%)$, psychologists $(1.0 \%)$, others (4.9\%) and did not answer (1.9\%). Regarding time of professional experience: $74.8 \%$ had over 13 years of professional experience, whereas $25.2 \%$ had less than 12 years. Considering time of experience within the institution: $8.7 \%$ reported less than 2 years, $38.8 \%$ between 3 and 12 years and $52.4 \%$ had over 13 years of experience. In terms of time of experience in current leadership position: $2.9 \%$ had less than one year; $61.2 \%$ between 1 and 7 years, $30.1 \%$ between 8 and 20 years and $5.8 \%$ over 21 years of experience in the position. Regarding weekly workload, 55.3\% remained at the organization between 40 and 49 hours per week, $21.3 \%$ between 20 and 39 hours, $21.3 \%$ between 50 and 60 hours or more and $2 \%$ from 10 to 19 hours.

There were no available studies in the literature about the psychometric analysis of the original instrument ${ }^{(19-20)}$. Regarding the psychometric validity of the instrument translated into Portuguese, internal consistency of the data was tested via Cronbach's alpha, as illustrated in Table 1, meaning that the questionnaire presented satisfactory reliability ${ }^{(21)}$. 
Table 1 - Cronbach's Alpha coefficient of studied dimensions São Paulo, SP, Brazil, 2014.

\begin{tabular}{lcccc}
\hline \multirow{2}{*}{ Dimension } & Items (n) & \multicolumn{2}{c}{ Cases (n) } & $\begin{array}{c}\text { Cronbach's } \\
\text { Alpha }\end{array}$ \\
\cline { 2 - 4 } & & valid & excluded & 05 \\
A & 06 & 98 & 05 & 0.84 \\
B & 21 & 87 & 16 & $0.93^{*}$ \\
D & 33 & 87 & 16 & $0.96^{*}$ \\
E & 09 & 95 & 08 & 0.72 \\
F & 11 & 93 & 10 & $0.93^{*}$ \\
G & 06 & 101 & 02 & 0.84 \\
\hline
\end{tabular}

Legend: A: Expectations and Actions Promoting Patient Safety; B: Hospital Management Support and Investment in Patient Safety; C: Patient Safety Climate; D: Communication Openness and Nonpunitive Response to Error; E: Organizational Learning; F: Teamwork; G: Feedback. TA: Type of Administration.

* The current literature considers 0.9 as the highest value of Cronbach's Alpha(22). Greater values suggest the existence of duplications or redundancy. Even though some dimensions obtained values greater than 0.9 , the consistency of the study was not affected, as regression discards possible collinearities present in the instrument, which can be attested to by the lower number of valid cases $(69<87)$, as shown in Table 2 .

Source: Created by the authors.

The linear regression model showed that the independent variables included in the model explained the dependent variable, implicating the assumption of the model's deterministic character. The F-test of joint significance was extremely significant, given that Prob $>\mathrm{F}$ was zero. Furthermore, $\mathrm{R}^{2}$ and adjusted $\mathrm{R}^{2}$ obtained high values, greater than $81 \%$ and $76 \%$, respectively. This means that the model described was capable of explaining at least $3 / 4$ of the variations of the independent variable ${ }^{(23)}$. In other words, the variables explained $81 \%$ of what the respondents credited to patient safety as part of organizational culture. Moreover, on conducting regression analysis to determine the extent to which each variable contributed to the model, only the dimensions Patient Safety Climate, Organizational Learning, and Type of Administration were statistically significant $(\mathrm{p} \leq 0.05)$. A limitation of this study was that it measured the perception of respondents towards the established dimensions, and not the dimensions themselves, possibly incurring in response bias. On the other hand, Type of Administration was factual: private, social organization, government or autarchy (Table 2).

The root MSE designates the standard deviation of the estimator, i.e., it is a measure analogue to the sample standard deviation, being that in this case the reference measure is the calculated estimator. Furthermore, correlation is a statistical measure that demonstrates how a variable behaves in relation to another. Beta coefficient of a model, in turn, demonstrates how a variable responds on the margin in relation to the dependent variable. Thus, Beta is a measure of sensitivity or marginal correlation between two variables. In turn, the significance test $(\mathrm{t})$ assesses via $\mathrm{P}|\mathrm{t}|$ the probability of the variable Beta equaling zero.

Table 2 - Regression Model: F-test, R² and coefficients of the adopted model - São Paulo, SP, Brazil, 2014.

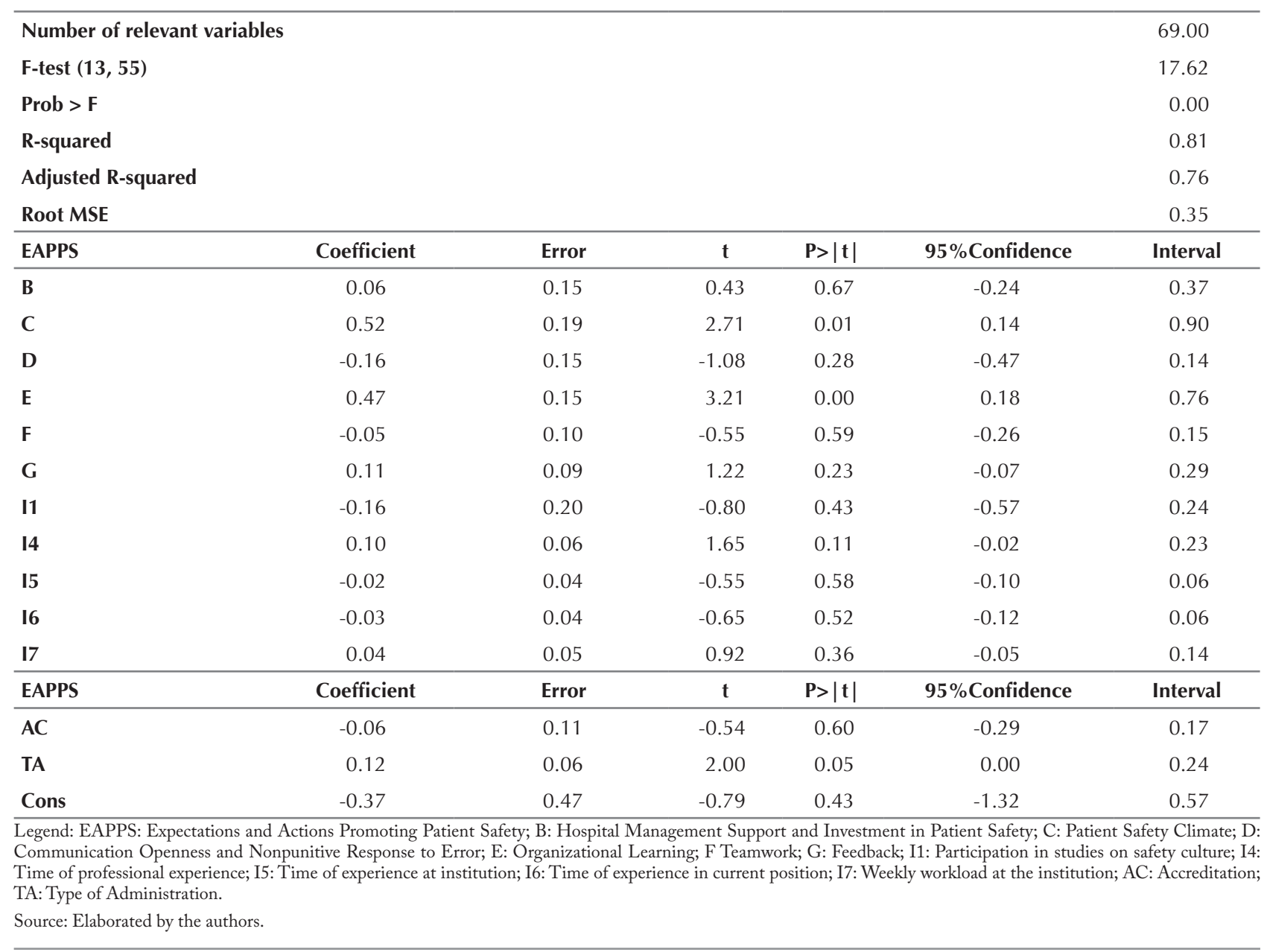


To verify whether the model changed when considering only the variables that passed the t-test for significance, a new linear regression was analyzed, including only 'Patient Safety Climate', 'Organizational Learning', and 'Type of Administration'(Table 3). Thus, when disregarding the other variables, the explanatory power $\left(\mathrm{R}^{2}\right)$ regressed to 0.79 . This means that the other variables removed from the model explained $2 \%$ of the variation of patient safety promoting actions in the studied institutions, whereas the other three variables (Patient Safety Climate, Organizational Learning, and Type of Administration) explained 79\% of the model.

The mean values of perceptions were close between dimensions, meaning that the values obtained were distributed relatively homogenously, especially between the dimensions
'Patient Safety Climate' and 'Organizational Learning', which behaved in the same manner to explain the perception of patient safety in organizations of different administrative natures. Another relevant factor was that these means varied increasingly from government to private organizations. Furthermore, there was less variation among private organizations when compared to government owned organizations (Table 4).

When analyzing the correlation between dependent and independent variables, Table 5 indicates that the correlation between Type of Administration and Expectations and Actions Promoting Patient Safety was negative, highlighting that, among the negative correlations, the strongest was that between Organizational Learning and Type of Administration (-0.54).

Table 3 - Regression Model: F-test, $R^{2}$ and coefficients for variables, in which $p<0.05$ - São Paulo, SP, Brazil, 2014.

\begin{tabular}{|c|c|c|c|c|c|}
\hline Number of relevant variables & & & & & 80.00 \\
\hline F-test (3. 76) & & & & & 95.32 \\
\hline Prob $>$ F & & & & & 0.00 \\
\hline R-squared & & & & & 0.79 \\
\hline Adjusted R-squared & & & & & 0.78 \\
\hline Root MSE & & & & & 0.36 \\
\hline Coefficient & Standard deviation & $\mathbf{t}$ & $\mathbf{P}>|\mathbf{t}|$ & $95 \%$ Confidence & Interval \\
\hline 0.56 & 0.11 & 4.93 & 0.00 & 0.33 & 0.79 \\
\hline 0.45 & 0.11 & 4.29 & 0.00 & 0.24 & 0.66 \\
\hline 0.10 & 0.04 & 2.51 & 0.01 & 0.02 & 0.19 \\
\hline-0.15 & 0.28 & -0.55 & 0.58 & -0.71 & 0.40 \\
\hline
\end{tabular}

Legend: EAPPS: Expectations and Actions Promoting Patient Safety; C: Patient Safety Climate; E: Organizational Learning; TA: Type of Administration. Source: Created by the authors.

Table 4 - Mean and standard deviation (SD) of perceptions measured through patient safety dimensions in different types of administration - São Paulo, SP, Brazil, 2014.

\begin{tabular}{|c|c|c|c|c|c|c|c|c|}
\hline TA & & A & B & C & D & $\mathbf{E}$ & $\mathbf{F}$ & G \\
\hline \multirow{2}{*}{ Private } & mean & 3.95 & 4.09 & 4.11 & 3.80 & 4.05 & 3.77 & 3.51 \\
\hline & SD & 0.60 & 0.52 & 0.50 & 0.52 & 0.47 & 0.53 & 0.87 \\
\hline \multirow{2}{*}{ Social organization } & mean & 3.74 & 3.69 & 3.55 & 3.61 & 3.87 & 3.33 & 3.46 \\
\hline & SD & 0.74 & 0.60 & 0.59 & 0.36 & 0.41 & 0.65 & 0.67 \\
\hline Autarchy & mean & 3.58 & 3.13 & 3.51 & 3.48 & 3.47 & 3.07 & 2.74 \\
\hline \multirow{2}{*}{ Government } & mean & 3.07 & 2.77 & 3.05 & 3.19 & 2.78 & 2.87 & 2.41 \\
\hline & SD & 1.04 & 0.96 & 0.97 & 0.77 & 0.94 & 1.05 & 1.13 \\
\hline \multirow{2}{*}{ Total } & mean & 3.56 & 3.43 & 3.58 & 3.51 & 3.52 & 3.23 & 2.96 \\
\hline & SD & 0.82 & 0.86 & 0.76 & 0.61 & 0.86 & 0.83 & 1.02 \\
\hline
\end{tabular}

Legend: A: Expectations and Actions Promoting Patient Safety; B: Hospital Management Support and Investment in Patient Safety; C: Patient Safety Climate; D: Communication Openness and Nonpunitive Response to Error; E: Organizational Learning; F: Teamwork; G: Feedback; TA: Type of Administration.

Source: Created by the authors.

Table 5 - Correlogram of relevant dimensions to the dependent variable - São Paulo, SP, Brazil, 2014.

\begin{tabular}{lcccc}
\hline & $\mathbf{A}$ & $\mathbf{C}$ & $\mathbf{E}$ & NA \\
\hline $\mathbf{A}$ & 1.00 & & & \\
$\mathbf{C}$ & 0.86 & 1.00 & & \\
$\mathbf{E}$ & 0.84 & 0.87 & 1.00 & \\
TA & -0.37 & -0.52 & -0.54 & 1.00 \\
\hline
\end{tabular}

Legend: A: Expectations and Actions Promoting Patient Safety; C: Patient Safety Climate; E: Organizational Learning; TA: Type of Administration.

Source: Created by the authors.

\section{DISCUSSION}

In this study, most participating professionals had at least 3 years of experience in their leadership position. Considering that $90.2 \%$ of the leaders had over 8 years of professional experience, and more than half $(67 \%)$ had worked at the studied hospital organization for more than 8 years, these were experienced professionals with a history within the organization. Therefore, it was possible to assume that they were inserted into the culture of the 
organizations they were a part of, in consonance with what was described in a study regarding the learning characteristics of organizations ${ }^{(11)}$.

Based on the perception of leaderships toward the observed dimensions, three variables stood out as more relevant to conditioning patient safety culture in the organizations: Patient Safety Climate, Organizational Learning and Type of Administration. This finding indicates that the effectiveness of patient safety actions depends not only on infrastructure, resources (material, technological, human and financial) and procedures relevant to the development of patient safety culture ${ }^{(24-25)}$, but also requires learning at all levels of the organization. Another finding of this study was that the participants in private organizations gave similar answers that gravitated around the mean score, whereas government organizations demonstrated greater variation among answers. It can be inferred that such uniform answers among private organizations represents a greater consolidation of the aspect related to ensuring patient safety within the scope of organizational culture, reflecting what has been described about the complexity of hospital management ${ }^{(24)}$. In turn, government organizations seemed to present greater capacity for Organizational Learning.

The correlation between 'Expectations and Actions Promoting Patient Safety' and 'Type of Administration' was higher among private institutions. This can be explained by the fact that the researched organizations allocate resources to increase their competitiveness in the market and improve their economic and financial results ${ }^{(25)}$. Thus, they adopt preventive measures to manage risks related to health care provision to reduce expenses associated with patient incidents, build client loyalty, and promote the institutional image. Among the negative correlations, the strongest one was between Organizational Learning and Type of Administration (-0.54). Ultimately, this can mean that according to participants' perceptions, private organizations presented a strengthened organizational culture due well-established and disseminated work processes. For this reason, they presented greater capacity of learning from identified mistakes and errors.

The relationship between 'Expectations and Actions Promoting Patient Safety' and 'Patient Safety Climate' presented a high Beta (0.86), which suggests the high relevance of the dimension among the four different administrative models. This indicates that the organizations valued aspects related to organizational investments (infrastructure, resources and processes) for the development of a safety culture.

Regarding the administrative nature of the organizations, not much can be done to value conditions that create a favorable cultural climate, given that their operational regimes are restricted by different legal frameworks, models of governance and economic and financial regimes. In practice, government organizations dispose of financing and resource allocation mechanisms that are strongly conditioned by the legal and political regime in force. On the other hand, private organizations, regardless of their lucrative or philanthropic nature, are conditioned by the pursuit for economic and financial results.

In terms of inserting the theme "patient safety" in the organizational climate and, consequently, its culture, it is important to keep in mind that hospital organizational culture is influenced by the work and power relationships that exist between the different professional profiles that compose such an environment. The specific attributions and competencies of each group can impregnate the culture of a given organization in such a way that does not value the principle of "learning from mistakes"(16). A possible yet difficult suggestion for future research would be to assess the specificity of patient safety in relation to how error reporting is valued in organizations with different types of administration.

To contribute to the incorporation of patient safety in organizational culture, two improvements related to the dimension of Organizational Learning stand out: the development of mechanisms that stimulate a culture of mutual trust, allowing for greater openness so that mistakes and errors can be reported, which allows for an analysis to correct processes and monitor the efficiency of the implemented barriers ${ }^{(24,26)}$; and the use of teamwork tools that contribute to the incorporation of the desired behaviors. This is an excellent strategy to incorporate patient safety-related behaviors and improve safety culture $^{(27)}$. Still with regards to the dimension of organizational learning, a comparison among the means attributed by the different groups in this study indicated that private organizations attributed a high level of importance to this dimension, followed respectively by social organizations, autarchies and government organizations.

Despite the importance of these findings, this study presents some limitations, starting with the number of hospitals that participated in the study. A greater number of participants could have resulted in different outcomes. Furthermore, a possible response bias may have resulted from the questionnaire, given that participants were able to indicate what they believed to be the best answer to the questions about the theme at hand and not what really happened in the organizations.

\section{CONCLUSION}

The present study showed that not all dimensions of patient safety culture hold equal weight when considering organizational culture. Thus, analyzing the culture of safety in health organizations in order to identify which dimensions need to be introduced or improved is relevant. Furthermore, such analysis can direct management to implement strategies that strengthen and increment the issue of safety in organizations, especially keeping in mind that changes in perceptions of safety culture can consume considerable resources and efforts.

In the group of leaderships in the studied hospitals, greater meaning was given to content related to the variables associated with Organizational Learning, Patient Safety Climate and Type of Administration. Of these, leaderships can act upon the dimensions related to the development of a safety climate, such as reporting AEs and introducing the theme in processes of ongoing organizational learning. 
The findings of this study strongly indicate that investing in actions and processes that strengthen organizational learning and improving safety climate can significantly contribute to increased awareness about the theme and, consequently, create safer processes not only for patients, but for the organization as a whole.

\section{RESUMO}

Objetivo: Identificar percepções das lideranças sobre as dimensões da cultura de segurança do paciente no cotidiano de hospitais de diferentes perfis administrativos: públicos, organizações sociais e privados, e realizar correlação entre as instituições participantes, de acordo com as dimensões da cultura de segurança do paciente utilizadas. Método: Estudo transversal de aspecto quantitativo obtido por meio da aplicação do instrumento Self Assessment Questionnaire 30, traduzido para a língua portuguesa. Os dados foram tratados com análise de variância (ANOVA), além das estatísticas descritivas, considerando como de significância estatística valores de $p$-valor $\leq 0,05$. Resultados: Segundo a percepção dos participantes do estudo, as dimensões significativas para a cultura de segurança do paciente foram Ambiente de Segurança do Paciente e Aprendizado Organizacional, com poder explicativo de $81 \%$. A média de respostas obtidas evidenciou que nas organizações privadas houve maiores valores atribuídos às questões, porém a correlação entre as dimensões foi mais forte nas organizações públicas. Conclusão: As dimensões da cultura de segurança do paciente têm valores distintos nas diferentes organizações hospitalares e a sua investigação possibilita identificar quais necessitam ser introduzidas ou aprimoradas para maior segurança do paciente.

\section{DESCRITORES}

Segurança do Paciente; Cultura Organizacional; Administração de Serviços de Saúde; Qualidade da Assistência à Saúde.

\section{RESUMEN}

Objetivo: Identificar percepciones de los liderazgos acerca de las dimensiones de la cultura de seguridad del paciente en el cotidiano de hospitales de distintos perfiles administrativos: públicos, organizaciones sociales y privados, y realizar la correlación entre las instituciones participantes, de acuerdo con las dimensiones de la cultura de seguridad del paciente utilizadas. Método: Estudio transversal de aspecto cuantitativo obtenido por medio de la aplicación del instrumento Self Assessment Questionnaire 30, traducido a la lengua portuguesa. Los datos fueron tratados con análisis de varianza (ANOVA), además de las estadísticas descriptivas, considerando como de significación estadística valores de $\mathrm{p}$-valor $\leq 0,05$. Resultados: Según la percepción de los participantes del estudio, las dimensiones significativas para la cultura de seguridad del paciente fueron Ambiente de Seguridad del Paciente y Aprendizaje Organizativo, con poder explicativo del $81 \%$. El promedio de respuestas obtenidas evidenció que en las organizaciones privadas hubo mayores valores atribuidos a las cuestiones, sin embargo la correlación entre las dimensiones fue más fuerte en las organizaciones públicas. Conclusión: Las dimensiones de la cultura de seguridad del paciente tienen valores distintos en las diferentes organizaciones hospitalarias y su investigación posibilita identificar cuáles necesitan introducirse o perfeccionarse para una mayor seguridad del paciente.

\section{DESCRIPTORES}

Seguridad del Paciente; Cultura Organizacional; Administración de los Servicios de Salud; Calidad de la Atención de Salud.

\section{REFERENCES}

1. Jha AK, Prasopa-Plaizier N, Larizgoitia I, Bates DW. Patient safety research: an overview of the global evidence. Qual Safety Heal Care. 2010;19(1):42-7.

2. Kohn LT, Corrigan JM, Donaldson MS. To err is human: building a safer health system. Washington: National Academy Press; 1999.

3. Reis CT, Martins M, Laguardia J. A segurança do paciente como dimensão da qualidade do cuidado de saúde um olhar sobre a literatura. Ciênc Saúde Coletiva. 2013;18(7):2029-36.

4. Sherman H, Castro G, Fletcher M, Hatlie M, Hibbert P, Jakob R, et al. Towards an International Classification for Patient Safety: the conceptual framework. Int J Qual Health Care. 2009;21(1):2-8.

5. Portugal. Ministério da Saúde; Direção Geral da Saúde. Estrutura Conceitual da Classificação Internacional sobre Segurança do Doente: relatório técnico final. Lisboa; 2011.

6. Daud-Gallotti R, Novaes HMD, Lorenzi MC, Eluf-Neto J, Okamura MN, Velasco IT. Adverse events and death in stroke patients admitted to the emergency department of a tertiary university hospital. Eur J Emerg Med. 2005;12(2):63-71.

7. Mendes W, Martins M, Rozenfeld S, Travassos C. The assessment of adverse events in hospitals in Brazil. Int J Qual Health Care. 2009; 21(4): 279-84.

8. Novaretti MCZ, Santos EDV, Quitério LM, Gallotti RMD. Nursing workload and occurrence of incidents and adverse events in ICU patients. Rev Bras Enferm. 2014; 67(5):692-9.

9. Word Health Organization. Global Status Report on Road Safety: time for action. Geneva: WHO; 2009.

10. Donaldson MS, editor. Measuring the quality of health care. Washington: National Academies Press; 1999.

11. Schein E. Three cultures of management: the key to organizational learning. Sloan Manage Rev. 1996;38(1):9-20.

12. Cooper MD. Towards a model of safety culture. Safety Sci. 2000;36(2):111-36.

13. Brasil. Ministério da Saúde; Agência Nacional de Vigilância Sanitária. Resolução RDC n. 36, de 25 de julho de 2013. Institui ações para a segurança do paciente em serviços de saúde e dá outras providências [Internet]. Brasília; 2013 [citado 2015 set. 13]. Disponível em: http://bvsms.saude.gov.br/bvs/saudelegis/anvisa/2013/rdc0036_25_07_2013.pdf 
14. Bognár A, Barach P, Johnson JK, Duncan RC, Birnbach D, Woods D, et al. Errors and the burden of errors: attitudes, perceptions, and the culture of safety in pediatric cardiac surgical teams. Ann Thorac Surg. 2008;85(4):1374-81.

15. Padilha KG. Ocorrências iatrogênicas na UTI e o enfoque de qualidade Rev Latino Am Enfermagem. 2001;9(5):91-6.

16. Malik AM, Schiesari LM. Gestão em saúde. Rio de Janeiro: Guanabara Koogan; 2011. Qualidade e acreditação; p. 325-8.

17. Brasil. Ministério da Saúde. Cadastro Nacional de Estabelecimentos de Saúde [Internet]. Brasília; 2014 [citado 2014 jun. 14]. Disponível em: http://cnes.datasus.gov.br/

18. Coelho RC. O público e o privado na gestão pública. 2 2a ed. Florianópolis: Departamento de Ciências da Administração, UFSC; 2012. p. 17-8.

19. Emergency Care Research Institute. Self-Assessment Questionnaire - SAQ 30: patient safety [Internet]. 2005 [cited 2014 June 08]. Available from: http://ps.mcic.com/appdocs/lps/ECRI\%20Patient\%20Safety\%20Self\%20Assessment\%20Questionaire\%202005.pdf

20. Clarke JR, Lerner JC, Marella W. The role for leaders of health care organizations in patient safety. Am J Med Qual. 2007;22(5):311-8.

21. Cronbach LJ, Meehl PE. Construct validity in psychological tests. Psychol Bull. 1955; 52(4):281-302.

22. Streiner DL. Being inconsistent about consistency: when coefficient alpha does and doesn't matter. J Pers Assess. 2003;80(3):217-22.

23. Anderson DR, Sweeney DJ, Williams TA, Camm JD, Cochran JJ. TA. Essentials of statistics for business and economics. 7th ed. Boston: Cengage Learning; 2014.

24. Klück M, Prompt CA. Hospitais: administração da qualidade e acreditação de organizações complexas. Porto Alegre: Da Casa. 2004. O Programa Brasileiro de Acreditação Hospitalar na Gestão da Qualidade Assistencial; p. 69-81.

25. Gama ZAS, Saturno PJ. A Segurança do paciente inserida na gestão da qualidade dos serviços de saúde. In: Brasil. Ministério da Saúde; Agência Nacional de Vigilância Sanitária. Assistência segura: uma reflexão teórica aplicada à prática. Brasília: ANVISA; 2013. p. 29-40.

26. Carvalho VT, Cassiani SH. Analysis of nursing professionals' behaviors in face of errors in medication administration. Acta Paul Enferm. 2002;15(2):45-54.

27. Frankel A, Leonard M. Update on safety culture [Internet]. 2013 [cited 2014 Dec 29]. Available from: https://psnet.ahrq.gov/perspectives/ perspective/144/update-on-safety-culture 